\section{BLACK-HEADED GROSBEAK AT PIERSON, MANITOBA}

\author{
by RICHARD W. KNAPTON*
}

On the evening of July 31,1974 , a Black-headed Grosbeak was misthetted on the Pierson Wildlife Management Area, some 7 miles outhwest of Pierson, Manitoba. The hird was examined in the hand by Dave Duncan of Winnipeg and by nyself, and was then shown to Ralph J. Nang of Pierson, after which it was eleased.

The bird was distinguished from the ose-breasted Grosbeak by its ecidedly yellowish-brown underparts ith very few streakings, and by its right lemon-yellow wing-linings. It vas most likely a female but could ave been a first-year male, paricularly as the underparts were so rightly coloured.

McNichol recently summarized nown records of the Black-headed irosbeak in Manitoba and listed only records, covering some 12 birds to $965 .{ }^{45}$ No records from 1965 to 1974 ave been uncovered. In Saskathewan, the species has been recorded $\mathrm{s}$ far east as Estevan but is a decidedly carce bird over much of the province, reeding sparingly in the Cypress Hills ith a breeding record from Last Mountain Lake. ${ }^{6} 27$ Indeed, the closest rea to the Pierson Wildlife Management Area in which the Blackeaded Grosbeak regularly occurs is long the Missouri River in North akota, some 150 miles southwest.' However, interestingly enough, ybrids between Black-headed and ose-breasted Grosbeaks have been pund only 60 miles south along the ouris River, 16 miles southeast of Minot ${ }^{3}$, thereby providing a greater otential for pure Black-headed rrosbeaks or hybrids to occur in the xtreme southwest, as opposed to other reas, of Manitoba.

Dept. of Zoology,

University of Manitoba,

Winnipeg, Manitoba

R3T 2N2
I should like to thank R. W. Nero for information supplied to me for this article.

'AMERICAN ORNITHOLOGISTS' UNION 1957. Checklist of North American Birds. Fifth ed. Baltimore.

${ }^{2}$ GODFREY, W. E. 1950. Birds of the Cypress Hills and Flotten Lake regions, Saskatchewan. Nat'l. Mus. Can. Bull. 120. Ottawa. 96 p.

"KROODSMA, R. L. 1974. Species-recognition behavior of territorial male Black-headed and Rose-breasted Grosbeaks (Pheucticus). Auk. 91:54-64.

${ }^{4} \mathrm{McNICHOLL}, \mathrm{M} .1965$. A possible sight record of the Black-headed Grosbeak in Manitoba. Blue Jay 23:77-78.

"McNICHOLL, M. 1966. Further note on the Black-headed Grosbeak in Manitoba. Blue Jay 24:70.

${ }^{6}$ MITCHELL, H. N. 1924. Birds of Saskatchewan. Can. Field-Nat. 38:101-118.

'SYMONS, R. D., and R. W. NERO. 1965. Blackheaded Grosbeak breeding record for southcentral Saskatchewan. Blue Jay 23:72-76.

\section{PROBABLE CINNAMON TEAL - BLUE-WINGED TEAL CROSS}

\section{by S. L. and J. A. WEDGWOOD*}

As waterfowl were returning in numbers, we drove west of Saskatoon on Sunday, April 27, 1975, paying special attention to the water bodies. On a slough (W1/2-18-36-8-W3) about a mile northwest of Rice Lake there was one duck unlike any we had seen before. Following half an hour of observation, debate and the consulting of field guides, we concluded this male bird was most likely a cross between a Cinnamon Teal and a Blue-winged Teal.

Our first impression was that we had come upon a Cinnamon Teal, a bird with which we were familiar, having seen it a number of times on the West Coast - but there were two differences. The body, breast and head were Cinnamon Teal: plain dark rusty red.

*610 Leslie Ave.

Saskatoon, Salskatchewan. 
the pate being darker, the tail black. However, there was a light flank patch which the Cinnamon does not have. On the Blue-winged Teal this patch is white; on the bird seen it was a light creamy-yellow or off-white depending on the observer. The second difference was on the face. The Cinnamon Teal's face is unmarked, whereas the bird we saw had a small white patch. This patch was less than a quarter the extent of the white crescent-shaped marking on the face of a Blue-winged Teal and was more frontally placed and not as sharply delineated as that crescent. Seen head on, both patches showed on the front of the face in line with the upper portion of the upper mandible, that is, in the region of the lores.

Wing markings were those of the two teals, which on flying birds are not separable in any event.

The bird was accompanying a female which was typical of the similar appearing Blue-winged and Cinnamon Teal females. While we were observing them, they were swimming, skip-flying and preening, movements which gave us many good views of the male.

Observing conditions were: $30-50$ yards, mid-day, overcast; $10 \mathrm{X}$ and $7 \mathrm{X}$ binoculars.

Dr. J. B. Gollop, Canadian Wildlife Service, later informed us that there are records of crossing between the two species. One that he drew to our attention was a hybrid male taken in Utah, on June 9, 1947.2 The description of the specimen is the same as for the Rice Lake bird with two exceptions: a white rather than an off-white flank patch and a full crescent face patch rather than a vestigal patch.

In the Blue Jay, 1971, Fred W. Lahrman' reported on a hybrid Cinnamon Teal-Blue-winged Teal he had photographed near Regina in 1970. We examined the transparencies on file in the Saskatchewan Museum of Natural History. The only marked difference was in the colour pattern of the body, the bird we observed being closer to the Cinnamon colouration than was the one in the Lahrman photograph. That is, the Rice Lake bird's body was a deeper chestnut. also lacked the Blue-winged Teal dark spots, marks present on th Regina bird.

'LAHRMAN, FRED W. 1971. Hybrid Cinnumo, Teal X Blue-winged Teal al Regina. Blue Jay' 2 28.

"WILSON, V. T. and J. B. VAN DENAKKEK 1948. A hybrid Cimnanon Teal-Blue-winged Ted al the Bear River Migratory Bird Refuge, Uta Auk 6.5: 316

\section{TRAGEDY IN A WREN HOUSE}

$$
\text { By C. G. RILEY* }
$$

A pair of wrens seemed to be well o the way to success in raising a family $i$ our nest house. Both adults had bee busily carrying food in. The youn were becoming vociferous, and the grotesque little heads could be seen ir side the 1 -inch entrance hole.

Then the male (?) abruptly disan peared. During the next 4 days th female (?) continued to feed the youn and then she too disappeared.

After a day of enforced listening the incessant hungry clamour, w broke down and began what we kne must be an ultimately futile progra of feeding the cluster of noisy ope mouths. Several times a day, flie dewinged moths, pieces of gardc worm, bits of ground beef, wer hungrily snatched from forceps unt appetites were seemingly satisfied $f$ the time being. Two busy days of th culminated with the cool night (4 deg. F.) of June 30 . The next mornit all was quiet.

One young bird had fallen out of th nest house the day before, and v believed we had been feeding the thr remaining ones. But when we openc the nest house we found five litt corpses, for a total brood of six. A appeared equally developed, we

\footnotetext{
* 1630 Wiggins Ave.,

Saskatoon, Saskatchewan.
} 